\title{
THE CHARACTERISTICS OF JAVANESE LANGUAGE IN BLORA DIALECT
}

\author{
Audrizan Wahyu Suprapto ${ }^{1)}$, Didit Kurniadi' ${ }^{2}$, Eko Heriyanto ${ }^{3)}$ \\ Language and Culture Faculty of AKI University \\ Email: audrizanwahyusuprapto@gmail.com
}

\begin{abstract}
Indonesia is a country that has many regional languages. The diversity of regional languages is a characteristic of Indonesia. One of them is the Javanese language which is used by the Javanese people and has a variety of dialects. Therefore, the writer is interested in conducting research on the characteristics of the Javanese dialect of Blora in accordance with sociolinguistic studies that examines the relationship between language and its speaking community. This is similar to the writer aim to analysis the differences between Blora, Temanggung and Mojokerto dialects. The writer also analyzes the use of Javanese speech level used by the people of Blora. This is because there are still many people who do not know the geographical location of Blora City. In this study, the writer uses a qualitative descriptive method and the data collection methods needed to analysis the data are simak method and cakap method. The analysis results showed that there are characteristics of the Blora dialect and there are differences between Blora, Temanggung and Mojokerto dialect. It can be concluded that the variations of the three dialects have different morphology, phonology, lexical and semantics. This is due to the diversity of dialect differences from the results of regional observations.
\end{abstract}

Keywords: Sociolinguistics, Javanese language, Dialect

\section{Introduction}

Language is a verbal expression that can be understood among human being. This opinion is related to Choudhury $(2014$, p.1), who stated that language is a means of expression. We express our feeling, emotional, thoughts, needs, desires etc. Language science consists of several branches of knowledge, there are, phonetic phonology, morphology, syntax, semantic, and pragmatics. For this reason, linguistic studies itself has many field specifications and sub-derivatives that specialize in studying elements of language in more depth.

Regional language is the naming of the language used by groups of people whose members show a relatively higher frequency of interaction between them compared to those who do not speak the regional language (Zulfahita et al., 2019). Indonesia has various regional languages. One of them is Javanese language. Javanese language is one of the languages used by the people of Indonesia. Javanese language has various kind of dialects. There are Semarang dialect, Pekalongan dialect, Blora dialect, Kudus dialect, Pati dialect, East Javanese dialect, etc. According to Junaidi et al (2016), dialect is a variation of a standard language characterized by regional or regional language variations and is a 
standard language that has minor differences in the fields of phonology, morphosyntax, semantics based on the area of use.

Regional variations distinguish the language used in one place from those used in another, even though the variations come from one language. In addition, dialectology studies language variations by treating them with a complete structure (Kridalaksana, 2001, p.42). Dialectology also studies language variation in all its aspects. The aspects in question are phonology, morphology, syntax, lexicon, and semantics. Dialect refers to the differences between various languages with different vocabulary, grammar and pronunciation. This issue is really exciting to analyse Blora dialect. In order to limit the discussion of this research is to analyse the characteristics of Blora dialect, differences between Blora dialect with Temanggung and Mojokerto dialect and analyse language variation of Javanese language used in Blora.

In this research, the method of data collection is used. According to Riduwan (2010, p.51), data collection techniques are one of the existing methods in data collection by using techniques or methods used by researchers to collect data. In this method, we used qualitative method to analyse the problem. This method of qualitative of analysis is used to do research about the characteristics of Blora dialect.

\section{Theoretical Review}

\subsection{Javanese Language}

In analyzing this thesis, the writer uses some theories. They are Javanese language, dialect and Blora culture. According to Zulaeha (2010), the Javanese language is one of the regional languages in Indonesia with a large number of users. Regions in Indonesia that use Javanese as their daily language include the provinces of Central Java and East Java. According to Hermadi in Gurning \& Ginting (2018), Javanese language is the language used as a language of daily interaction in Java, especially Central Java. Meanwhile, Javanese in East Java is also not a standard Javanese language because in general it uses rough Javanese (ngoko). With these facts, it is not surprising that the Indonesian people are able to become speakers of two languages, namely the mother tongue which is the regional language and Indonesian as the national language (Suharyo, 2018).

Javanese language is also one of Indonesia's cultural heritages that must be preserved so that it can be passed down from generation to generation, especially by the younger generation of Javanese people. In use, Javanese has its own script, namely Javanese script, a different dialect from each region, as well as unggahungguh basa (Javanese etiquette) is different. Javanese is the language of the Malay language family which has many levels in the use of the language (Mijianti, 2017). The use of levels is related to ethics as the basic of communication (Hasanah et al., 2015). Ethics in communication includes all values and norms that become a reference in the act and behave. There are three levels, namely ngoko, madya and krama (Sukarto, 2010).

Levels of the language in use is also different depending on who the speaker. Daily conversations with ngoko level used to talk with peers or younger. Javanese ngoko is a form of unggah-ungguh basa to Javanese using vocabulary in the form 
of ngoko lexicon. Ngoko is usually used for the language of intimacy or close relations with friends (Jauhari \& Purnanto, 2019). Madya is a mixed language between ngoko and krama and is used to speak to people who are not familiar or have a higher social level. Meanwhile, Javanese krama is used to talk to people who have a higher position or power, for example, young people with their parents or employees with their superiors. The higher level of krama is karma inggil. Krama inggil is a language with vocabulary used to communicate with parents as a sign of politeness and reluctance to older people (Yuliyani \& Mukminin, 2020). The affixes that appear in Javanese krama are all in the form of krama lexicons, for example, dipun-, -ipun, and-aken. Krama has two variant forms, namely krama lugu and krama inggil.

\subsection{Dialect}

Indonesia consists of hundreds of regional dialects and languages, almost 700 of which have regional dialects and languages in the Republic of Indonesia (Kemendikbud, 2019). Dialect is a variant of a language whose existence is determined by the background of the speakers origin. According to Nuryani et al (2018), dialect is a variation of the language of a group of speakers whose numbers are relative, who are in one place, region, or certain area. Dialects are usually classified based on geography, but can be based on other factors, such as social factors.

Javanese dialect can be classified into several groups. This grouping is based on the dialect used for society in terms of geography (Zulaeha, 2010). The division of these groups includes the western part of Javanese group, namely Banten dialect, Cirebon dialect, Tegal dialect, Banyumasan dialect, Bumiayu dialect. This dialect group is often referred to as Javanese ngapak. The central Javanese group, namely Pekalongan dialect, Kedu dialect, Bagelen dialect, Semarang dialect, the north east coast dialect (Jepara, Rembang, Demak, Kudus, Pati), Blora dialect, Surakarta dialect, Yogyakarta dialect, and Madiun dialect.

The eastern Javanese group, namely East Javanese pantura dialect (Tuban, Bojonegoro), Surabaya dialect, Malang dialect, Jombang dialect, Tengger dialect, and Banyuwangi dialect (also known as the Osing language). This dialect group is called the East Javanese. Javanese of Solo-Yogyakarta dialect is considered the standard Javanese. This is because the areas of Solo (Surakarta) and Yogyakarta are palace areas. Where the Kraton is considered a meaningful symbol by Javanese people in general.

Dialect is a variety of language used by a group of language speakers who have relatively the same characteristics, and are associated with geography. According to Holmes (2013), dialects consist of 2 types, namely geographic dialects and social dialects. One of the characteristics of dialects is that speakers of the same language dialect still understand each other, and what distinguishes each of these dialects lies in the phonological, morphological, lexical, and syntactic aspects. While the distribution of dialects is based on regional or geographical factors (regional), time factors (temporal), and social factors (Kridalaksana, 2009).

Temporal dialect is due to the natural environment where the dialect is used throughout its development. Dialects are produced because of two complementary 
factors, namely the time and place factors. Geographical Dialect is the study of language variations based on differences in a place in one language area. Meanwhile social dialect according to Kridalaksana (2009), dialect is a variation of language that varies according to the user; variations of the language used by certain groups of a group of linguists, namely social dialects.Therefore, it is easy to distinguish other groups of people. The group consists of groups of work, age, activity, gender, education, and so on. Social dialect refers to the dialect or speech spoken by the social class of the speaker

\subsection{Blora Culture}

Blora is a regency located in the province of Central Java, the eastern part of which is adjacent to East Java, namely the Bojonegoro Regency. Blora Regency has a variety of arts. The cultural diversity possessed by Indonesia has its uniqueness and characteristics that become a strength for the nation, but a lack of understanding of cultural values that are also diverse can trigger conflicts which are a factor of the nation's weakness (Widiastuti, 2013).

One of the arts in Blora Regency is singo barong. Singo barong is one of the cultures in Indonesia Singo barong is one of the cultures in Indonesia which is still reflected in the characteristics of the people, especially by the people of Blora, such as: spontaneity, kinship, simplicity, rudeness, toughness, compactness, and courage based on truth. In its performance, Singo Barong is an art in the form of a theater resembling a big lion as the ruler of a very ferocious haunted forest.

Blora Regency has several nicknames based on its culture and abundant natural wealth, including the city of barongan, city of satay, city of teak and oil, city of Samin, and city of Blora Mustika. Barongan is one of the popular arts in Blora. This art is displayed in various events, both family events, events to celebrate the independence of Blora to village events such as gasdeso (sedekah bumi). This is what makes people give the nickname Blora as a barongan city.

Blora satay city is nicknamed the city of satay because the satay from Blora is famous for its special seasoning, namely peanut sauce and the way it is served using teak leaves. Satay Blora can be enjoyed with white rice or with lontong. In addition to its unique culture and cuisine, Blora is also named as city of teak and oil. The abundance of teak wood can be used as a raw material in the manufacture of furniture. Teak production in Blora is the largest teak production in Java. Blora teak wood is known to have the best quality in Indonesia and is even known in various countries. In addition to the city of teak, regional wealth which is widely available in various places, especially in Blora, is oil. This oil, apart from being managed by the state through BUMN, also managed by BUMD.

Meanwhile, Mustika is an acronym for Advanced, Superior, Healthy, Orderly, Beautiful, Continuous and Safe. From the meaning of Blora Mustika, the people of Blora are obliged to realize Blora's ideals to become a Maju, Unggul, Sehat, Tertib, Indah, Kontinyu and Aman. On the gate on the border of the city there is the inscription Blora Mustika, that's why people give the nickname as the city of Mustika. In addition, Blora Regency is known as the city of Samin, namely the word Samin is actually the name of a warrior from Blora, Samin Surosentiko. 


\section{Research Method}

\subsection{Method of Data Collection}

Data collection is an important method in a research.Data collection technique is a method used by researchers to collect research data from data sources (subjects and research samples). Data collection was carried out to obtain the information needed in order to achieve the research objectives. The data collection method taken by the writer is the listening method with recording and note-taking techniques and interviews. This research was conducted online using social media via telephone or video call. If blocked by the internet network, it can be done via short messages.

\subsection{Method of Data Analysis}

The data analysis method is one of the important components in the data analysis process. According to Mahsun in Erina \& Suartana (2016) data analysis techniques are efforts made to classify data. This method is part of the analysis process where the collected data is then processed to produce data conclusions according to the problem in the study. In this study the writer use padan method. This method is used by the writer to analyze in solving research problems that come from outside the language concerned.

\section{Discussion}

\subsection{The characteristics of Blora dialect}

The characteristics of the Blora dialect can be viewed in terms of phonology, morphology, syntax, semantics or lexicon in everyday speech used by the Blora people.

\begin{tabular}{|c|c|c|c|c|}
\hline & Blora Dialect & Example & Meaning & Purpose \\
\hline $\begin{array}{l}\text { Ndoplang } \\
\text { District }\end{array}$ & $\begin{array}{l}\text { The lexical -re } \\
/ r I /\end{array}$ & $\begin{array}{l}\text { Iyo sesok re } \\
\text { Ndak piye } \\
\text { re? }\end{array}$ & $\begin{array}{l}\text { Yes, } \\
\text { tomorrow } \\
\text { right } \\
\text { How is this? }\end{array}$ & \multirow{3}{*}{$\begin{array}{l}\text { In addition } \\
\text { this suffix } \\
\text { is used to } \\
\text { express a } \\
\text { question or } \\
\text { statement. }\end{array}$} \\
\hline $\begin{array}{l}\text { Blora } \\
\text { District and } \\
\text { City }\end{array}$ & $\begin{array}{l}\text { The lexical - } \\
\text { leh /lch/ }\end{array}$ & $\begin{array}{l}\text { Gausah leh } \\
\text { Tenane leh? } \\
\text { Ndang } \\
\text { mangan leh }\end{array}$ & $\begin{array}{l}\text { No need } \\
\text { Sure? } \\
\text { Hurry up to } \\
\text { eat }\end{array}$ & \\
\hline $\begin{array}{l}\text { Japah } \\
\text { District }\end{array}$ & $\begin{array}{l}\text { The lexical - } \\
\text { jek/jkk/ }\end{array}$ & $\begin{array}{l}\text { Piye jek? } \\
\text { Kok ngono } \\
\text { jek }\end{array}$ & $\begin{array}{l}\text { How is this? } \\
\text { Why is that? }\end{array}$ & \\
\hline
\end{tabular}

The characteristic of Blora dialect is special a lexical. In data above there are additional lexical-re /rI/, -leh $/ l \varepsilon h /$, and -jek /je?/. These three additional lexical have the same meaning only used by Blora people in different areas. For suffix -re is found in Ndoplang District, suffix -leh is more widely used in every Blora District and also city of Blora. While the suffix -jek is found in Japah District.

Another characteristic of the Blora dialect is the pronunciation of the last syllable $-\boldsymbol{u} \boldsymbol{h}$ to $-\boldsymbol{o h}$. While the last syllable $-\boldsymbol{i} \boldsymbol{h}$ becomes $-\boldsymbol{\varepsilon} \boldsymbol{h}$ and the last syllable

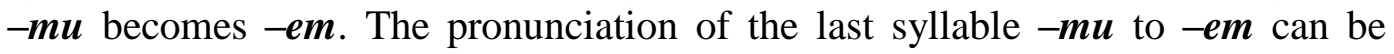
viewed from a morphological point of view. Because in the characteristic of the 
Javanese dialect, Blora dialect, there are words that experience shortening and affixes simultaneously. Words resulting from the shortening process that undergo affixation, are indicated by the addition of the suffix $-\mathrm{em} / \boldsymbol{\mathrm { m }} /$.

While the pronunciation of the last syllable $-\boldsymbol{e h} / \boldsymbol{s h} /$ and $-\boldsymbol{o h} / \boldsymbol{h} /$ can be viewed from a phonological point of view which consists of several phonemes. The pronunciation of the last syllable includes a vowel phoneme change.

a. The phoneme $/ \mathrm{i} /$ is realized as $/ \varepsilon /$

b. The phoneme $/ \mathrm{u} /$ is realized as $/ \mathrm{J} /$

\begin{tabular}{|c|c|c|}
\hline Last Syllable & Blora Dialect & Meaning \\
\hline $\begin{array}{l}\text { The phoneme }-u h \text { becomes } \\
-o h / s h /\end{array}$ & $\begin{array}{l}\text { Ngunduh = } \\
\text { ngundoh/yundsh/ } \\
\text { Utuh }=\text { utoh } / \text { utsh/ } \\
\text { Butuh = butoh /butsh/ } \\
\text { Suruh = suroh /sursh/ }\end{array}$ & $\begin{array}{l}\text { Harvest } \\
\text { Intact } \\
\text { Need } \\
\text { This meaning is betel } \\
\text { leaf }\end{array}$ \\
\hline $\begin{array}{l}\text { The phoneme-ih becomes - } \\
\text { eh/ch/ }\end{array}$ & $\begin{array}{l}\text { Gurih = gureh } / \text { gurch/ } \\
\text { Putih = puteh/putch/ } \\
\text { Sugih = sugeh } / \text { sugch/ }\end{array}$ & $\begin{array}{l}\text { Crunchy } \\
\text { White color } \\
\text { Rich }\end{array}$ \\
\hline $\begin{array}{l}\text { The phoneme }-m u \text { becomes } \\
-e m / s m /\end{array}$ & $\begin{array}{l}\text { Bukumu = bukuem } \\
\text { /bukuəm/ } \\
\text { Omahmu = omahem } \\
\text { /omıhəem/ } \\
\text { Mripatmu = mripatem } \\
\text { /mrip^təm/ } \\
\text { Klambimu = klambiem } \\
\text { /klımbiəm/ }\end{array}$ & $\begin{array}{l}\text { Your book } \\
\text { Your house } \\
\text { Your eyes } \\
\text { Your clothes }\end{array}$ \\
\hline
\end{tabular}


The Blora dialect also has a unique idiom, namely "mboyak". In dialectological studies, the word "mboyak" is included in the linguistic element, namely semantics which studies the meaning of a word in language. The word "mboyak" itself is an expression which expresses a sense of indifference or ignorance to the problems at hand or things that are not too important for him. So the word mboyak has many meanings depending on the context of the sentence being discussed, namely "mboh lah, wis ben kono, karepem dewe, alah mbuh, terserah kono" and etc. In the data above the word "mboyak ah" is defined as "alah mboh" (whatever) or "wes ben kono" (yes, let it be).

There is a language typical of the Blora dialect, namely the word "jabake" which means "always like that". Thus the word "jabake" is a linguistic element, namely semantics. In addition to the word "mboyak" which has many meanings, "jabake" also has more than one meaning. Another meaning of "jabake" is "gosh!" as expression of surprise when you hear important information.

\subsection{The differences between Blora dialect and other dialects}

In this other dialect difference, the writer will take the difference between Blora dialect and Temanggung dialect and the East Java dialect, namely Mojokerto dialect. The writer choosesTemanggung, Mojokerto and Blora dialectsbecause there are different vocabularies that have the same language but different meanings between the Central Java and the East Javanese dialect. These dialect differences will be analyzed based on dialectological studies.

1. Phonology

The variations of the Javanese language from the two regions experience changes in vowel phonemes, changes in consonant phonemes and changes in vowel and consonant phonemes.

a. Vowel Change

\begin{tabular}{|l|l|l|l|l|}
\hline Word & $\begin{array}{l}\text { Pronuncation of } \\
\text { Blora Dialect }\end{array}$ & Word & $\begin{array}{l}\text { Pronunciation of } \\
\text { Temanggung Dialect }\end{array}$ & Meaning \\
\hline Mlete & [mlItI] & Mloto & [mloutou] & Arrogant \\
\hline
\end{tabular}

\begin{tabular}{|l|l|l|l|l|}
\hline Word & $\begin{array}{l}\text { Pronuncation of } \\
\text { Blora Dialect }\end{array}$ & Word & $\begin{array}{l}\text { Pronunciation of } \\
\text { Mojokerto Dialect }\end{array}$ & Meaning \\
\hline Medon & {$[$ madoun] } & Modon & [moudoun] & Turun \\
\hline Kedal & {$[$ kIdhal] } & Kidal & {$[$ kidh $\mathrm{l}]$} & $\begin{array}{l}\text { Use left } \\
\text { hand }\end{array}$ \\
\hline
\end{tabular}

From the results of the table above, there is a change in the vowel change between Blora and Temanggung dialect is /e/ to /o/, namely [mlItI] and [mloto] with the meaning of arrogant. While in the vowel change between Blora and Mojokerto dialect is /ə/ to /o/, namely [madoun] and [moudoun] which means down and /e/ to /i/, namely [kId $\mathrm{ll}$ ] and [kidsl] with the meaning of using left hand.

b. Consonant Change

\begin{tabular}{|l|l|l|l|l|}
\hline Word & Blora Dialect & Word & $\begin{array}{l}\text { Temanggung } \\
\text { Dialect }\end{array}$ & Meaning \\
\hline Cedak & {$[c ə d \wedge k]$} & Cepak & {$[c ə p \wedge k]$} & Close \\
\hline
\end{tabular}




\begin{tabular}{|l|l|l|l|l|}
\hline Anyep & [^nyap] & Anyes & [^nyas] & Cold \\
\hline
\end{tabular}

In the table above, the consonant in Temanggung dialect $/ \mathrm{d} /$ becomes $/ \mathrm{p} /$, namely $[c ə d \wedge k]$ and $[c ə p \wedge k]$ which have a meaning that is close.

c. Vowel and Consonant Change

\begin{tabular}{|c|c|c|c|c|}
\hline Word & \begin{tabular}{|l|} 
Blora \\
Dialect \\
\end{tabular} & Word & $\begin{array}{l}\text { Temanggung } \\
\text { Dialect }\end{array}$ & Meaning \\
\hline Arep & [^rəp] & Arek & [^rck] & Will \\
\hline Njupok & [nзupsk] & Njikuk & [nzi:kuk] & Take \\
\hline Njongok & [nзээวk] & \begin{tabular}{|l} 
Njagong \\
\end{tabular} & [nзıgगク] & Sit down \\
\hline Ora weruh & [ors waroh] & Mberuh & [mboruh] & $\begin{array}{ll}\text { Do } & \text { not } \\
\text { know }\end{array}$ \\
\hline
\end{tabular}

\begin{tabular}{|l|l|l|l|l|}
\hline Word & $\begin{array}{l}\text { Blora } \\
\text { Dialect }\end{array}$ & Word & $\begin{array}{l}\text { Mojokerto } \\
\text { Dialect }\end{array}$ & Meaning \\
\hline Njupok & [nzupsk] & Njokok & {$[$ [ndzok 5 k $]$} & Take \\
\hline
\end{tabular}

In the first word, the vowel phoneme /a/ becomes $/ \varepsilon /$ and the consonant phoneme $/ \mathrm{p} /$ becomes $/ \mathrm{k} /$. The second word changes the vowel phoneme $/ \mathrm{u} /$ to $/ \mathrm{i} /$, $\mathrm{J} / \mathrm{becomes} / \mathrm{u} /$ and the consonant phoneme $/ \mathrm{p} /$ becomes $/ \mathrm{k} /$. In the third word, the vowel phoneme $/ \mathrm{J} /$ becomes $/ \mathrm{s} /$ and the consonant phoneme $/ \mathrm{g} /$ becomes $/ \mathrm{g} /$ and $/ \mathrm{k} /$ becomes $/ \mathrm{y} /$. As for the latter, the vowel phoneme $/ \mathrm{o} /$ becomes $/ \mathrm{u} /$ and the consonant phoneme $/ \mathrm{w} /$ becomes $/ \mathrm{mb} /$ where $/ \mathrm{mb} /$ is a consonant combination.

In the Mojokerto dialect, the vowel phoneme $/ \mathrm{u} /$ becomes $/ \mathrm{J} /$ and the consonant phoneme $/ \mathrm{p} /$ becomes $/ \mathrm{k} /$.

d. Additional of Sound

\begin{tabular}{|l|l|l|l|l|}
\hline Word & Blora Dialect & Word & Mojokerto Dialect & Meaning \\
\hline Mlayu & [mlayu $]$ & Mblayu & [mblayu $]$ & Run \\
\hline
\end{tabular}

The table above explains that there is an additional of sound $/ \mathrm{b} /$ in the Mojokerto dialect, namely [mblayu].

2. Lexical

\begin{tabular}{|c|c|c|c|c|}
\hline No. & $\begin{array}{l}\text { Pronunciation of } \\
\text { Blora Dialect }\end{array}$ & $\begin{array}{l}\text { Pronuncation of } \\
\text { Temanggung } \\
\text { Dialect }\end{array}$ & $\begin{array}{l}\text { Pronunciation } \\
\text { of Mojokerto } \\
\text { Dialect }\end{array}$ & Meaning \\
\hline 1. & [wadsh bontst] & [tlakam] & [tepık] & Rice box \\
\hline 2. & [sılıyın] & [pogว] & & $\begin{array}{l}\text { Place to save } \\
\text { food }\end{array}$ \\
\hline 3. & [njolok] & [nзıgวभy] & [longoh] & Sit down \\
\hline 4. & [Aku] & [nyэy] & [awakku] & $\mathrm{Me}$ \\
\hline 5. & [kowe] & [pe^y] & [awnkmu] & You \\
\hline 6. & [mboynk] & [jidhor] & [gı yarckan] & Do not care \\
\hline 7. & [^пуар] & [^nyas] & [^dəm] & Cold \\
\hline 8. & [lıtır] & [tritikın] & [lutır] & $\begin{array}{l}\text { In front of the } \\
\text { house }\end{array}$ \\
\hline 9. & [ors warUh] / & [mbarUh] & [g^ yarti] & Do not know \\
\hline
\end{tabular}




\begin{tabular}{|c|c|c|c|c|}
\hline & [orn dunUy] & & & \\
\hline 10. & [mbalIn] & [mbiyin] & [ndıblak] & Naughty \\
\hline 11. & [kıtes] & [g^ndhUl] & [kıtes] & Papaya \\
\hline 12. & [cablok] & [gigsl] & [rutoh] & Fall down \\
\hline 13. & [kednl] & [nicel] & [kidnl] & Use left hand \\
\hline 14. & [bodhig^sın] & [krınjIn] & [ygnteli] & Not polite \\
\hline 15. & [tewel] & [gori] & [tewel] & Young jackftuit \\
\hline 16. & [gambrey] & [trempoloy] & 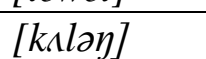 & Cans \\
\hline 17. & [g^mpil] & [sipil] & 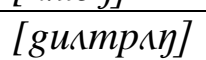 & So easy \\
\hline 18. & [nзирлk] & [ndzikuk] & [ndzokjk] & Take \\
\hline 19. & [sukar] & [jəmck] & [jəmck] & Muddy \\
\hline 20. & [russh] & [ragat] & [rusuh] & Dirty \\
\hline 21. & [jadII]]/[kiwın] & {$[w c]$} & [jadII] & Bathroom \\
\hline 22. & [tekyen] & [ncycy] & [teyenan] & Rusty \\
\hline 23. & [ora kod $₫$ k] & [ora tcyey] & [g^iso] & Can not \\
\hline 24. & [^rəp] & [^rck] & {$[k \wedge t I]$} & Will \\
\hline 25. & [mlete] & [mloto] & [sวmbวy] & Arrogant \\
\hline 26. & [tık kiro] & {$[t \wedge k \eta g \supset s i]$} & [tık kiro] & I think \\
\hline 27. & [mbılck] & [wasIs] & [kamintar] & Smart \\
\hline 28. & [cədnk] & [cop^k] & [idak] & Close \\
\hline 29. & [dipın] & [Amben] & [mbıla] & Bed \\
\hline 30. & [g^sdesว] & [nyıdrın] & - & Sedekah bumi \\
\hline 31. & [og^k onว] & [nวnว] & {$\left[\begin{array}{ll}g \wedge & \partial n \supset]\end{array}\right]$} & Nothing \\
\hline
\end{tabular}

3. Morphology

There are morphological differences, namely the addition of a suffix at the end of a sentence. The Blora dialect has the suffix -leh, -re and -jek which is usually spoken by the people of Blora. As for the Temanggung dialect, there is the suffix "nda'an" which is often used in the speech of the Temanggung people when they are communicate. While in the Mojokerto dialect has the suffix -seh and usually Mojokerto people use harsh words.

In addition, there is also the addition of the beginning of a word in a sentence for Temanggung dialect. A prefix is an affix that is added at the beginning of a word. In the Temanggung dialect there is the addition of " $h a$ " at the beginning of the word, for example "ha njuk piye?", "ha mberuh". But for the Blora dialect there are no additions at the beginning of the word.

\section{Semantics}

There are semantic differences between Blora dialect and Temanggung dialect. "Mele-mele" in Blora dialect means that the word is full, while in Temanggung dialect it means sticking her tongue out or in other means is "melet".

"Gleyor" in Blora dialect has the meaning of "sempoyongan" (people when walking will fall), while in the Temanggung dialect it means long beans.

"Luweh" in Temanggung dialect has the meaning of being indifferent, while in Blora dialect it has more meaning. 


\subsection{The variation of Javanese language used in Blora}

Based on Javanese speech, this dialect is a social language and includes the level of ngoko or rough language. So, in the Blora area, krama (smooth) and madya (a mixture of krama and ngoko) levels are still used in addition to ngoko lugu social dialect level.

The languages used in the Blora district are Indonesian and Blora Javanese in speech level are ngoko, madya and krama by their respective users.

\begin{tabular}{|l|l|l|}
\hline Krama Alus & Ngoko Lugu & Meaning \\
\hline Wonten menopo & Ana apa & What's the matter \\
\hline Maringi & Menehi & Give \\
\hline Sare & Turu & Sleep \\
\hline Rumiyin & Ndisik & First \\
\hline
\end{tabular}

\begin{tabular}{|l|l|l|}
\hline Ngoko Lugu & Ngoko Alus & Meaning \\
\hline Kowe & Sampeyan & You \\
\hline Lungo & Tindak & Go \\
\hline Arep & Ajeng & Will \\
\hline
\end{tabular}

\section{Conclusion}

Based on the results of data analysis and discussion, the characteristic of Blora dialect use of -leh /lkh/, -jek/je?/, or -re /rI/ suffixes. This suffix is used by Blora people in various areas of Blora district. For the use of -jek, it is used by the people in the Japah subdistrict and the use of -re by the people in the Ndoplang subdistrict. While the use of the suffix -leh is more widely used by the people of Blora, especially in the city of Blora.In the field of phonology, the vowel changes $/ i /$ is realized into $/ \varepsilon /$ and $/ \mathrm{u} /$ is realized into $/ 0 /$.While in the field of morphology, Blora dialect occur a shortening process that undergoes affixation, marked by the addition of the suffix $-\mathrm{em} / \mathrm{\partial m} /$.

The people of Blora also have an idiom, namely "mboyak" which is commonly used among young people. This idiom has many meanings depending on the context of the sentence. The dialect characteristics of Blora people are different from Temanggung dialect and East Javanese dialects, especially Mojokerto area. If the Blora dialect has a characteristic in the use of the suffix leh /lkh/, -jek/je?/ or -re /rI/ but Temanggung dialect uses the suffix in a sentence, namely $-n d a$ 'an. The Temanggung community also has a characteristic prefix " $h a$ " at the beginning of a sentence.

While the people of Blora use the prefix "jabake" unlike the Mojokerto people. The characteristic of dialect that is owned by Mojokerto people is the use suffix -seh. The people of Mojokerto in daily communication use rougher language than the people of Central Java. Even saying swear words to communicate with close friends is common for them. 
Based on the description and analysis, it can be concluded that Blora, Temanggung, Mojokerto dialect only experienced small changes, namely changes in vowel and consonant sounds and slightly different meanings. The languages used in the Blora district are Indonesian and Javanese ngoko, madya and krama speech levels. However, young peopleespecially in Blora city, mostly use Javanese ngoko or Indonesian language to communicate each others.

The writer hopes that more researchers will research the study of Javanese dialects, especially the Blora dialect and find more characteristics of the Blora dialect. So that the Blora dialect can be known to many people, especially for the location of the Blora city area which is still largely unknown to the public other than the people of Central Java.

Based on the conclusion above, the writer gives advice to the readers that the local language must be preserved and the importance of teaching the younger generation to communicate using a polite Javanese speech level. The piece above reflects how rich the value of the Javanese language is in terms of linguistics and the richness of a language reflects the high civilization of its people.

\section{References}

Choudhury, R. U. (2014). The Role of Culture in Teaching and Learning of English. Express, an International Journal of Multi Disciplinary Research, 1(4), 1-20.

Gurning, B., \& Ginting, A. (2018). Javanese Language Maintenance of Intermarriages in Rantau Utara. Jurnal Linguistik Terapan Pascasarjana, 15(3), 217-225. https://doi.org/https://doi.org/10.24114/lt.v15i3.14774

Hasanah, E., Sofyan, A., Indonesia, J. S., Sastra, F., \& Jember, U. (2015). Jember dan Bahasa Jawa Standar. 1-11.

Holmes. (2013). An introduction to sociolinguistics (fourth edition).Routledge.

Jauhari, E., \& Purnanto, D. (2019). The Use of Javanese as a Tool of Expression for Solidarity Politeness in the Ethnic Chinese Community in the Javanese Arek Cultural Area. 338(Prasasti), 140-143. https://doi.org/https://doi.org/10.2991/prasasti-19.2019.22.

Junaidi, Yani, J., \& Rismayeti. (2016). Variasi Inovasi Leksikal Bahasa Melayu Riau di Kecamatan Pulau Merbabu. Jurnal Pustaka Budaya, 3(1), 1-17.

Kemendikbud. (2019). Statistik Kebahasaan. Kemendikbud.

Kridalaksana, H. (2001). Principles of Linguistic Change. Blackwell.

Kridalaksana. (2009). Kamus Linguistik (edisi keempat). PT Gramedia Pustaka Utama.

Mijianti, Y. (2017). Peran Bahasa Jawa dan Bahasa Melayu untuk Bahasa.

Riduwan. (2010). Skala Pengukuran Variabel-Variavel Penelitian. Alfabeta.

Suharyo. (2018). Nasib Bahasa Jawa dan Bahasa Indonesia dalam Pandangan dan Sikap Bahasa Generasi Muda Jawa. 13(2), 244.

Sukarto, K. A. (2010). Analisis Kontrastif Sistem Morfemis Nomina Bahasa JawaIndonesia. $91-100$.

Widiastuti. (2013). Analisis SWOT Keragaman Budaya Indonesia. Jurnal Ilmiah Widya, 1(1), 8-14. https://e-journal.jurwidyakop3.com/index.php/jurnalilmiah/article/view/21. 
Yuliyani, E. R., \& Mukminin, A. (2020). The Influence of Javanese Language Usage in The Sociodrama Method of Increasing Politeness Behavior of Children Ages 5-6 Years. BELIA: Early Childhood Education Papers, 9(1), 20-26. https://doi.org/10.15294/BELIA.V9I1.28693.

Zulaeha, I. (2010). Dialektologi Dialek Geografi dan Dialek Sosial.Graha IImu.

Zulfahita, Z., Yanti, L., \& Purnamawati, E. (2019). Analisis Komponen Makna Verba "Menyakiti" dalam Bahasa Melayu Dialek Sambas (Kajian Semantik). JP-BSI (Jurnal Pendidikan Bahasa Dan Sastra Indonesia), 4(2), 104. https://doi.org/http://dx.doi.org/10.26737/jp-bsi.v4i2.1087 